\title{
Microscopical assessment of explanted allograft heart valves: a limited contribution of histopathology to the pathogenic mechanism of the graft failure in long-term explants
}

\author{
Ondřej Fabiánn a,b,c, Mariia Havovad, Roman Gebauere, Rudolf Porubane, \\ Ondřej Maternae, Jaroslav Špatenkaf, Jan Burkert', Václav Chaloupeckýe, \\ Vilém Rohn', Filip Mikušc, Eliška Obešlovác, Jan Janoušek ${ }^{\mathrm{e}}$ \\ a Clinical and Transplant Pathology Centre, Institute for Clinical and Experimental Medicine, Prague \\ ${ }^{b}$ Department of Pathology and Molecular Medicine, Thomayer Teaching Hospital, 3rd Faculty of Medicine, Charles \\ University, Prague \\ ' Department of Pathology and Molecular Medicine, 2nd Faculty of Medicine, Charles University and Motol University \\ Hospital, Prague \\ ' Department of Cardiovascular Surgery, 2nd Faculty of Medicine, Charles University and Motol University Hospital, Prague \\ e Children's Heart Centre, 2nd Faculty of Medicine, Charles University and Motol University Hospital, Prague \\ ${ }^{f}$ Transplant Centre, 2nd Faculty of Medicine, Charles University and Motol University Hospital, Prague
}

\section{ARTICLE INFO}

\section{Article history:}

Submitted: 16. 10. 2020

Revised: 28. 10. 2020

Accepted: 28. 10. 2020

Available online: 24. 6. 2021

\section{Klíčová slova:}

Explantace

Histopatologie

Chlopenní alograft

Rejekce

Selhání
SOUHRN

Pozadí studie: Kryoprezervované chlopenní alografty (CAHV) v současné době představují konduity volby vykazující delší dobu přežití v porovnání s jinými typy chlopenních protéz. Nicméně téměř všichni pacienti v průběhu času rozvinou časné nebo pozdní selhání alograftu. Přesný mechanismus selhání či prípadná role buněčné nebo humorální rejekce však zůstávají nejasné. $V$ této studii jsme se zaměřili na mikroskopickou strukturu CAHV s ohledem na dobu trvání implantace, hodnotili stupeň degenerativních změn a pátrali po známkách celulární rejekce.

Metodika: Do studie bylo prospektivně zařazeno 24 pacientů s CAHV a jeden pacient s chlopenním xenograftem, kteří podstoupili explantaci konduitu v období od listopadu 2017 do května 2020. Zaznamenán byl věk pacientů v době implantace, doba trvání implantace, typ konduitu, hlavní diagnóza př́iemce a počet předchozích implantací. Mikroskopická struktura konduitů byla hodnocena pomocí světelné mikroskopie s užitím základních barvicích metod i imunohistochemie.

Výsledky: Všechny konduity byly kompletně avitální, s úseky nekróz, hyalinizace, kalcifikací, metaplastické kosti a přerůstání fibrózním pannem. Ve třech prípadech byly zastiženy okrsky zánětu rejekčního charakteru. Tři další pacienti vykazovali v průběhu operace i následně mikroskopicky známky subakutní infekční endokarditidy. Jak tíže mikroskopických změn, tak i přítomnost rejekčních infiltrátů byly nezávislé na době trvání implantace či jakékoliv jiné klinické proměnné.

Závěry: Histopatologické hodnocení explantovaných konduitů může přispět k objasnění přesného patogenetického mechanismu selhání alograftu. Nicméně mikroskopická struktura dlouhodobých explantátů je často nespecifická a známky celulární rejekce jsou mírné. Přínosnější tak může být mikroskopické vyšetření krátkodobých explantátů.

(c) 2021, ČKS.

\section{ABSTRACT}

Background: Cryopreserved allograft heart valves (CAHV) currently represent conduits of choice showing longer event-free survival compared to other types of prostheses. However, almost all patients develop early or late allograft failure. The exact mechanism of the failure and eventual role of cellular or antibody-mediated rejection remain uncertain. In this study, we targeted the microscopical structure of CAHV in correlation to the duration of implantation, assessed the degree of degenerative changes and searched for signs of cellular rejection.

Address: MUDr. Ondřej Fabián, Clinical and Transplant Pathology Centre, Institute for Clinical and Experimental Medicine, Vídeňská 1958/9, 14021 Prague 4, e-mail: ondrejfabian5@gmail.com DOI: 10.33678/cor.2020.098 
Methods: 24 patients with CAHV and one patient with xenograft heart valve who required conduit explantation in the period of 11/2017-5/2020 were prospectively enrolled in the study. Age of the patients at the time of implantation, duration of implantation, type of conduit, main diagnosis and number of previous implantations were recorded. Conduits were subjected to light microscopy and the microscopic structure was assessed using basic staining methods and immunohistochemistry.

Results: All conduits were completely non-vital, with areas of necrosis, hyalinization, calcification, metaplastic bone formation and pannus overgrowth. Foci of rejection-type inflammatory infiltrate were noted in three cases. Three other patients showed perioperative and microscopical signs of subacute infective

Keywords: Allograft heart valve Explantation Failure Histopathology Rejection endocarditis. Both severity of the microscopical changes and presence of rejection-type infiltrate were independent of duration of implantation or any other clinical variable.

Conclusions: Histopathological assessment of explanted conduits may contribute to understanding of exact pathogenic mechanisms of allograft failure. However, the microscopic appearance of long-term explants is often non-specific and signs of cellular rejection are sparse. Examination of short-term and intermediate-term explants may be more beneficial.

\section{Introduction}

Cryopreserved allograft heart valves (CAHV) represent conduits of choice showing better hemodynamics, higher resistance to infections, lower risk of thromboembolic events and superior longevity compared to other types of allografts. ${ }^{1-3}$ However, all implanted allografts inevitably reach the failure requiring replacement or another form of surgical intervention. Negative predictors of graft failure stem from clinical studies and include small age of donor and recipient, low weight of recipient, small size of allograft or aortic type of allograft. ${ }^{2-6}$ Histopathological examination of explanted allografts is not a part of routine biopsy practice and studies describing their microscopical appearance are limited in number. The exact pathophysiological mechanism of allograft failure and an eventual role of cellular or antibody-mediated rejection thus remain uncertain.

In this study, we aimed at the microscopical structure of the explanted allografts. We assessed the degree of degenerative changes with regards to the duration of implantation, evaluated the presence of rejection-type inflammatory infiltrate and searched for any other histopathological variables that could alleviate the cause of the graft failure.

\section{Materials and methods}

All patients with CAHV (ten pulmonary, seven aortic, and eight not specified) and one patient with xenograft heart valve implanted in the right ventricular outflow tract position, whom reached failure and required explantation in our center in the period from November 2017 to June 2020 were prospectively enrolled in the study. Age of the patients at the time of implantation varied from 1 month to 24 years (mean 59, median 31 , inter-quartile range 13-62 months). Duration of implantation ranged from 6 months to 23 years (mean 131, median 133, inter-quartile range 68-197 months). Main diagnosis of the recipient and number of previous implantations were also recorded. All the clinical details are summarized in Table 1.

The explanted conduits were fixed in $10 \%$ formalin and decalcified. After that, they were dissected and submitted to histopathological evaluation by light micros- copy. Specimens were embedded in paraffin blocks and sections of $2 \mu \mathrm{m}$ thickness were taken. All the microscopical slides were stained with hematoxylin and eosin. To properly assess the degree of structural deterioration, additional stains and immunohistochemistry highlighting individual components of the arterial wall and valvar cusps were performed. All samples were stained with Masson's trichome highlighting smooth muscle cells and fibrous tissue, Weigert's resorcin fuchsin highlighting the elastic fibers and alcian blue/periodic acid-Shiff stain demonstrating the presence of glycosaminoglycans. For the immunohistochemistry, 1- $\mu \mathrm{m}$ tissue sections were deparaffinized and specific primary antibodies were used: anti-vimentin (DAKO, at dilution $1: 100$ ) highlighting the overall cellularity of the sample, anti-h-caldesmon (BioSB, at dilution $1: 100$ ) demonstrating smooth muscle cells and anti-CD34 (BioGenex, at dilution $1: 40$ ) staining the endothelial cells. To highlight signs of cellular-type immune rejection, immunohistochemical stains of CD20 (DAKO, at dilution $1: 300$ ), CD3 (BioGenex, at dilution $1: 100)$ and CD8 (DAKO, at dilution $1: 200$ ) antigens were performed and the number of positive cells per 1 high power field $(\times 400)$ was counted. HRP/DAB PolyDetector (Bio SB) was used as a detection kit for all the aforementioned antibodies.

\section{Ethical considerations}

Legal representatives of the patients signed an informed consent form for inclusion into the study. The study was approved by the Ethics Committee of Motol University Hospital.

\section{Results}

At the gross examination, all the explanted conduits appeared extensively calcified and fibrotic, with markedly reduced valvar cusps. In three cases (patients number 11,14 , and 23), the perioperative macroscopic appearance was suggestive for infective endocarditis. On the microscopical level, all the conduits were completely non-vital, with loss of original trilaminar structure. Therefore, an exact quantification of individual histopathological changes by grading system was not possible. The- 
Table 1 - Clinical characteristics of the patients

\begin{tabular}{|c|c|c|c|c|c|c|c|c|c|}
\hline Patient No. & Sex & $\begin{array}{l}\text { Age at } \\
\text { implantation } \\
\text { (months) }\end{array}$ & $\begin{array}{l}\text { Duration of } \\
\text { implantation } \\
\text { (months) }\end{array}$ & $\begin{array}{l}\text { Site of } \\
\text { implantation }\end{array}$ & Graft type & $\begin{array}{l}\text { Pulmonary/ } \\
\text { Aortic }\end{array}$ & $\begin{array}{l}\text { Main dia- } \\
\text { gnosis }\end{array}$ & $\begin{array}{l}\text { Previous } \\
\text { implantations } \\
\text { (n) }\end{array}$ & $\begin{array}{l}\text { Infective } \\
\text { endocarditis }\end{array}$ \\
\hline 1 & $M$ & 25 & 20 & RVOT & CAHV & $P$ & TGA, VSD & 2 & No \\
\hline 2 & M & 7 & 6 & RVOT & CAHV & A & PA, VSD & 0 & No \\
\hline 3 & $\mathrm{~F}$ & 51 & 64 & RVOT & CAHV & $P$ & PA, VSD & 2 & No \\
\hline 4 & $M$ & 2 & 54 & RVOT & xenograft & $\mathrm{N} / \mathrm{A}$ & TA & 1 & No \\
\hline 5 & $\mathrm{~F}$ & 25 & 142 & RVOT & CAHV & A & PA, VSD & 1 & No \\
\hline 6 & $M$ & 14 & 172 & RVOT & CAHV & $P$ & PA, VSD & 1 & No \\
\hline 7 & $\mathrm{~F}$ & 15 & 88 & RVOT & CAHV & $P$ & $P A, V S D$ & 1 & No \\
\hline 8 & $\mathrm{~F}$ & 21 & 197 & RVOT & CAHV & A & PA, VSD & 1 & No \\
\hline 9 & $\mathrm{~F}$ & 1 & 54 & RVOT & CAHV & $\mathrm{N} / \mathrm{A}$ & TA & 1 & No \\
\hline 10 & $M$ & 36 & 186 & RVOT & CAHV & N/A & AS, ROSS & 1 & No \\
\hline 11 & $M$ & 211 & 97 & RVOT & CAHV & A & TOF & 2 & Yes \\
\hline 12 & $M$ & 50 & 83 & RVOT & CAHV & $\mathrm{N} / \mathrm{A}$ & DORV & 1 & No \\
\hline 13 & $\mathrm{~F}$ & 59 & 69 & RVOT & CAHV & A & TA & 4 & No \\
\hline 14 & $M$ & 96 & 208 & RVOT & CAHV & $P$ & TOF & 0 & Yes \\
\hline 15 & $M$ & 7 & 11 & RVOT & CAHV & N/A & DORV & 1 & No \\
\hline 16 & $M$ & N/A & N/A & RVOT & CAHV & A & TOF & 0 & No \\
\hline 17 & M & 24 & 222 & RVOT & CAHV & $\mathrm{N} / \mathrm{A}$ & TA & 2 & No \\
\hline 18 & $M$ & 11 & 123 & RVOT & CAHV & $P$ & PA, VSD & 1 & No \\
\hline 19 & $\mathrm{~F}$ & 122 & 202 & RVOT & CAHV & $P$ & TOF & 1 & No \\
\hline 20 & $M$ & 48 & 282 & RVOT & CAHV & N/A & DORV & 1 & No \\
\hline 21 & $M$ & 38 & 197 & RVOT & CAHV & A & TGA, VSD & 1 & No \\
\hline 22 & $\mathrm{~F}$ & 1 & 146 & RVOT & CAHV & $P$ & PA, VSD & 1 & No \\
\hline 23 & $M$ & 289 & 254 & RVOT & CAHV & $P$ & TOF & 1 & Yes \\
\hline 24 & $\mathrm{~F}$ & 71 & 111 & RVOT & CAHV & N/A & TOF & 2 & No \\
\hline 25 & $\mathrm{~F}$ & 193 & 157 & RVOT & CAHV & $P$ & TGA, VSD & 1 & No \\
\hline
\end{tabular}

A - aortic; AS - aortic stenosis; CAHV - cryopreserved allograft heart valve; DORV - double outlet right ventricle; $F$ - female; $M$ - male; P - pulmonary; PA - pulmonary atresia; ROSS - Ross-Konno procedure; RVOT - right ventricular outflow tract; TA - tricuspid atresia; TGA - transposition of the great arteries; TOF - tetralogy of Fallot; VSD - ventricular septal defect.

re were extensive degenerative changes with large areas of necrosis, followed by fibrosis and hyalinization. Hyalinized areas were hypocellular and consisted predominantly by collagenous extracellular matrix. Apart from that, extensive nodular calcifications and even a metaplastic bone were focally present. Elastic fibers were numerous in necrotic areas, but substantially fragmented and crumbled. In fibrotic areas, elastic component was markedly reduced. Deposits of glycosaminoglycans were focally present. Valvar cusps were found only in a form of small fibrotic and necrotic remnants. In all patients, there was a fibrotic pannus overgrowth from the luminal surface. The immunohistochemical assessment of vimentin antigen was negative in the wall of the conduit, positive cells were found only in the fibrous tissue of pannus and fibrous adhesions around the conduit. $\mathrm{H}$-caldesmon stain was negative as well. CD34 antigen showed almost complete loss of endothelial layer, preserved only in a few remnants. In one case (patient number 2 ), the microscopical appearance was different. There was a predominant necrosis affecting both the conduit wall and the free valvar cusps. Fibrosis was less prominent, and calcifications were small and delicate. Foci of re- jection-type inflammatory infiltrate were noted only in three cases (patients' number 22, 24, and 25). The inflammatory cells consisted mostly of CD8+ T-lymphocytes with a smaller number of CD8 negative CD3+ T-cells and CD20+ B-cells. Overall histopathological structure of explanted conduits is demonstrated in Figures 1A-1J. Duration of implantation did not substantially differ from the rest of the patients. Patients with perioperative suspicion for infective endocarditis showed extensive areas of necrosis with rich histiocytic reaction around the necrotic foci. Surfaces of the conduits were covered by fibrinous and purulent exudate with clusters of Gram-positive cocci. The microscopical picture was thus consistent with the clinical diagnosis.

\section{Discussion}

All patients with implanted conduit develop graft dysfunction or failure requiring surgical intervention. The cause of the failure is most likely multifactorial, with contribution of both immune and non-immune mechanisms. However, a direct causative effect of the immu- 

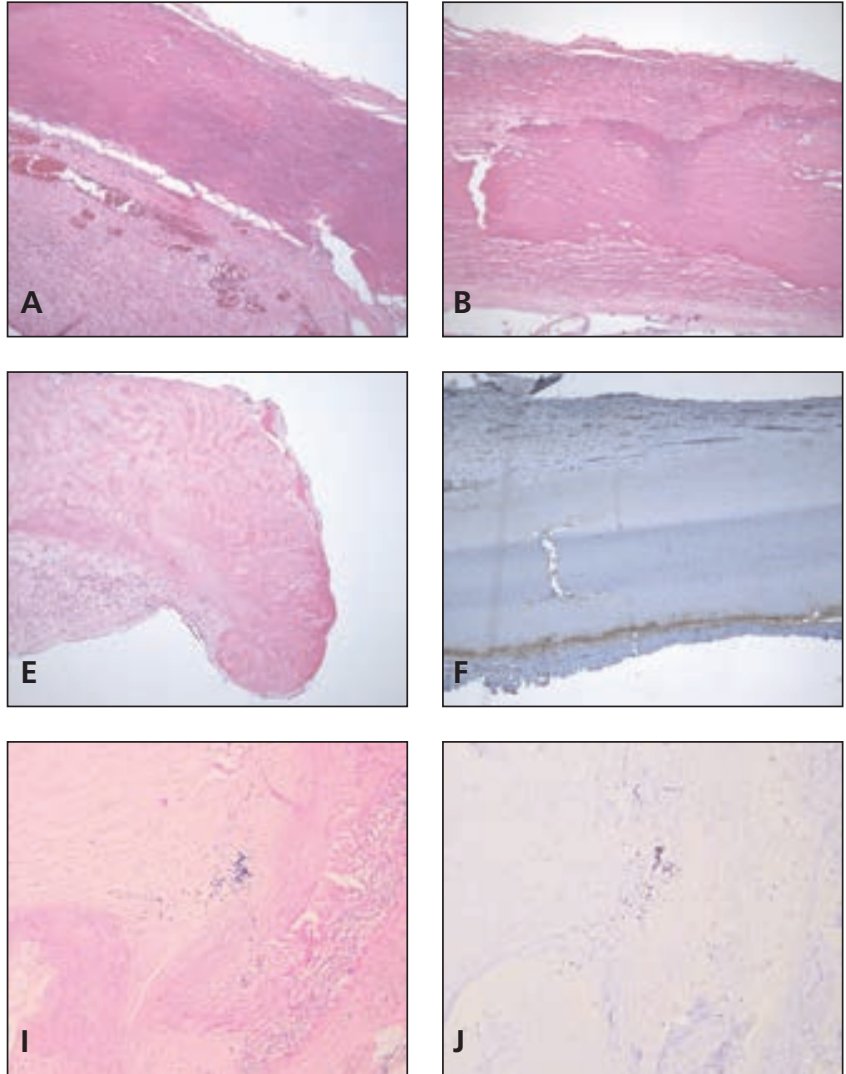

Fig. 1 - Microphotographs showing the histopathological appearance of explanted conduit. (A) The wall of the conduit shows extensive necrosis with dystrophic calcium deposits and fragmented elastic fibers (hematoxylin and eosin, 100x). (B) Focus of calcification in the wall of the conduit (hematoxylin and eosin, 200x). (C) Necrotic wall of the conduit with fibrous pannus overgrowth from the luminal side (hematoxylin and eosin, 200x). (D) Necrotic wall of the conduit with fragmented elastic fibers and fibrous pannus overgrowth (Weigert's resorcin fuchsin, 200x). (E) Acellular remnant of valvar cusp with fibrotic overgrowth (hematoxylin and eosin, 200x). (F) Immunohistochemical assessment of vimentin antigen is negative in the necrotic wall of the conduit and focally positive in fibroblasts of the pannus (on the top) and fibrous adhesions (at the bottom) (100x). (G) Immunohistochemical assessment of $\mathrm{h}$-caldesmon antigen showing absence of smooth muscle cells in the wall of the conduit (200x). (H) Immunohistochemical assessment of CD34 antigen demonstrating complete absence of endothelial cells (200x). (I) Focus of rejection-type inflammatory infiltrate in the wall of the conduit (hematoxylin and eosin, 200x). (J) The inflammatory infiltrate consists mostly of CD8+ lymphocytes (200x).

ne reaction is still not confirmed. Some authors suggest that early graft failure might be immune-mediated, while the failure of long-term implants may be caused predominantly by non-immune degenerative process. Stronger immune response can be expected also in pediatric patients. Basket et al. ${ }^{5}$ proposed that frequent occurrence of early graft dysfunction between 6 and 12 months after implantation in pediatric patients is probably immunologically driven. Vogt et al. ${ }^{7}$ assessed conduits from both adult patients and infants explanted between 8 months and 9 years after implantation. All pediatric cases showed signs of cellular rejection,
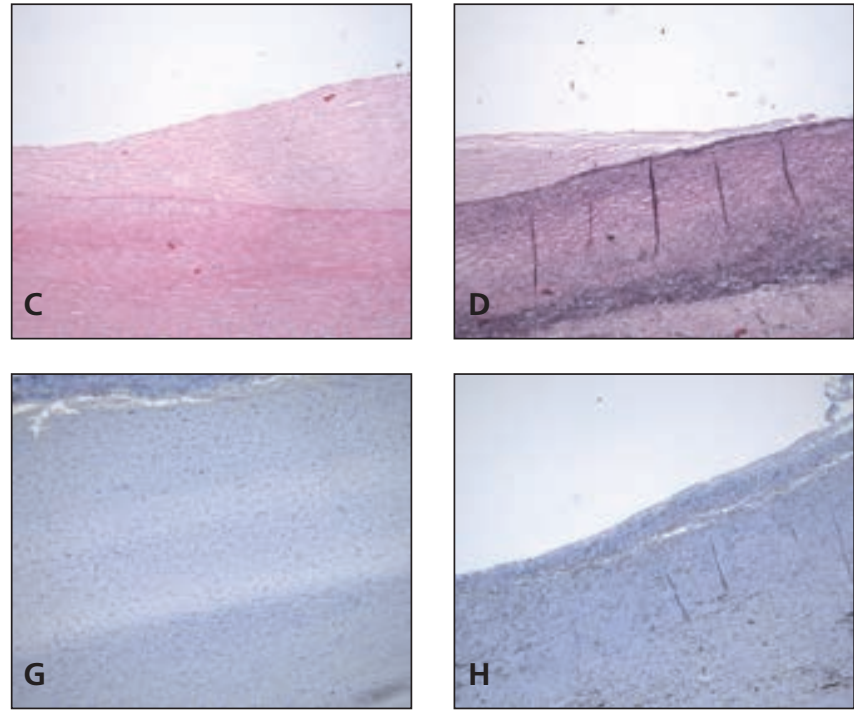

but in the adult group it was only $9 \%$. In a study by Koolbergen et al., ${ }^{8}$ the authors assessed 40 explanted conduits with mean recipient age 18 years. During first year after implantation, all conduits lost their internal trilaminar structure and developed substantial loss of cellularity. $78 \%$ of the grafts also showed signs of ceIlular rejection.

The level of immunogenicity of the graft is probably related to the degree of cellular preservation, since more preserved grafts keep higher amounts of viable immunogenic cells. This led to the introduction of decellularized allografts. Decellularization represents a promising way to eliminate valve tissue viability as a possible reason for the accelerated allograft deterioration due to immune related factors. ${ }^{9}$ Data from our previous work (not published yet) support this premise, since we demonstrated an association between reduced cellular component of cryopreserved allografts and decreased number of antigen-presenting dendritic cells. On the other hand, involvement of cellular rejection in a graft failure is still not fully elucidated and therefore using immunosuppression in high-risk patients (i.e. children or patients who underwent several graft transplantations) in the form of short course low dose postoperative therapy cannot be justified. ${ }^{10,11}$

A significant contribution to understand the immunemediated process of graft deterioration stem from the assessment of the valves acquired from hearts transplanted as a whole organ. Neves et al. ${ }^{12}$ compared microscopical appearance of five such valves with seven explanted conduits. Valves excised from whole hearts had almost normal microscopic structure, showing only mild fibrous thickening on the free edges of the cusps. On the other hand, the explanted conduits demonstrated marked degenerative changes with extensive areas of hyalinization, calcifications and loss of original trilaminar structure. Rejection-type inflammatory infiltrates were found in three conduits. Mitchell et al. ${ }^{10}$ described similar findings in their study on 33 explanted conduits and 16 whole hearts. The microscopical appearance of valves excised from transplanted hearts had almost physiological 
histological appearance, even in patients who developed heart failure due to acute rejection. One of the possible explanations may be a different microvasculature of the myocardium decelerating the blood flow and enhancing the possibility of mononuclear cell binging. A faster laminar blood flow on the surface of the heart valves may serve as a possible protective mechanism against the margination of the inflammatory cells. ${ }^{10}$

A contribution of antibody-mediated rejection in graft failure remains obscure. Koolbergen et al. ${ }^{8}$ found no deposits of IgG nor C3 in any of the explanted conduits in their study. However, they described a transient elevation of ICAM leukocyte adhesive molecule expression on the valvar cusps of the conduits explanted up to 1 year after implantation. Antibody-mediated rejection thus may manifest as an early and short-term phenomenon.

Individual microscopical changes appearing during the process of graft degeneration can be reconstructed from previous studies. One of the first observed changes is a loss of endothelium. Due to its high sensitivity to ischemia and traumatization, endothelial cell breakdown starts already at the time of multiorgan harvest and continues during the cryopreservation, subsequent thawing and handling of the conduit. ${ }^{13,14}$ Goffin et al. ${ }^{15}$ described a substantial loss of endothelia in conduits explanted a few hours after the implantation, accompanied by small stromal hemorrhages and influx of neutrophils. Since the endothelium represents a highly immunogenic structure, its absence may decrease the immunogenicity of the graft. ${ }^{16}$ On the other hand, unprotected surface of the valve may enhance an influx of plasma proteins and subsequent alteration of its extracellular matrix. The process may resemble the development of atherosclerosis, with endothelial dysfunction and subsequent fibrosis and calcification. ${ }^{8}$ In next days, process of the cellular lysis and structural deterioration with progressive loss of interlayer demarcations and loss of interstitial cells continues. Mural thrombi and stromal mononuclear inflammatory cell infiltration may be present. ${ }^{10}$ During the second week after implantation, signs of early healing process may be seen, with recipient fibroblasts proliferating from fibrous anulus towards the free edges of the cusps. ${ }^{15}$ Such a pannus overgrowth is highly variable. It may develop because of previous insult, represent a foreign body reaction or appear as a result of thrombus organization. As a non-thrombotic layer, it may decrease the risk of mural thrombosis. On the other hand, it may lead to valve dysfunction. ${ }^{11}$ Intermediate-term implants (up to 1 year after implantation) show marked deterioration of the internal structure of the conduits with fragmentation and loss of elastic fibers. Valvar cusps are markedly flattened and reduced, containing almost no vital cells. ${ }^{10}$ Long-term implants (years after implantation) are non-vital, with undistinguishable layers, substantial loss of the elastic component, marked reduction of valvar cusps, presence of nodular calcifications and variable pannus overgrowth. ${ }^{10}$ At the end, there is very little of donor-derived interstitial cells in such implants. O'Brien et al. ${ }^{17}$ were able to cultivate small amount of donor fibroblasts even 9 years after the implantation. However, such a small group of cells is unlikely to contribute to anatomically appropri- ate cellularity capable of functional matrix remodeling. It is likely that a durability of the grafts largely depends on the quality of the original collagenous skeleton.

In our study, all explanted conduits were markedly degenerated, with complete loss of cellular elements and extensive areas of necrosis, fibrosis, calcifications and pannus overgrowth. The changes were uniform in all patients except for one conduit, which was explanted 6 months after implantation and showed earlier signs of degeneration with predominant necrotic areas. We can speculate that the development of necrosis precedes a process of fibrosis and calcification. However, calcification may develop also as a direct consequence of disrupted extracellular matrix, which may serve as a nucleation center. ${ }^{18}$ Due to uniformity of the histopathological findings, no association could be found with any of the clinical variables such as main diagnosis of the recipient, age at implantation, duration of implantation, type of the valve or number of previous implants. Rejection-type inflammatory infiltrates were apparent in three cases. With regards to the small overall age of the patients in the study (mean age was 4 years and 11 months), we could expect more cases with microscopic signs of cellular rejection. However, a vast majority of the conduits were long-term explants, with average 10 years and 11 months duration of implantation. It is presumable that specific morphological signs that could eventually alleviate an etiopathogenetic mechanism of the graft failure had ceased or were covered by extensive degenerative changes.

The study has several limitations. It is a descriptive, single center study with small number of patients. In addition, the predominance of long-term explants with advanced degenerative changes and paucity of rejection-type inflammatory infiltration did not allow exact objectivization and grading of individual microscopical changes.

\section{Conclusions}

Graft failure is an inevitable phenomenon with involvement of both immune and non-immune mechanisms. Histopathological assessment of explanted conduits may contribute to our understanding of exact pathogenic mechanisms. However, the microscopical appearance of long-term explants is often non-specific and signs of cellular rejection are sparse. Examination of short-term and intermediate-term explants may be more beneficial.

\section{Acknowledgements}

We would like to thank Azzat al-Redouan for reviewing the manuscript.

\section{Conflict of interests}

The authors declare no conflict of interests.

\section{Funding}

This work was supported by the project (Ministry of Health, Czech Republic) for conceptual development of research organization 00064203 (University Hospital Motol, Prague, Czech Republic). 


\section{References}

1. Albert JD, Bishop DA, Fullerton DA, et al. Conduit Reconstruction of the Right Ventricular Outflow Tract. Lessons Learned in a Twelve-Year Experience. J Thorac Cardiovasc Surg 1993; 106:228-236.

2. Bielefeld MR, Bishop DA, Campbell DN et al. Reoperative Homograft Right Ventricular Outflow Tract Reconstruction. Ann Thorac Surg 2001;71:482-488.

3. Tweddell JS, Pelech AN, Frommelt PC, et al. Factors Affecting Longevity of Homograft Valves Used in Right Ventricular Outflow Tract Reconstruction for Congenital Heart Disease. Circulation 2000;102(19 Suppl 3):III130-III135.

4. Niwaya K, Knott-Craig CJ, Lane MM, et al. Cryopreserved Homograft Valves in the Pulmonary Position: Risk Analysis for Intermediate-Term Failure. J Thorac Cardiovasc Surg 1999;117:141-147.

5. Baskett RJ, Ross DB, Nanton MA, et al. Factors in the Early Failure of Cryopreserved Homograft Pulmonary Valves in Children: Preserved Immunogenicity? J Thorac Cardiovasc Surg 1996;112:1170-1179.

6. Kalfa DM, Loundou A, de Gorce YN, et al. Pulmonary Position Cryopreserved Homograft in non-Ross Patients: How to Improve the Results? Eur J Cardiothorac Surg 2012;42:981-987.

7. Vogt PR, Stallmach T, Niederhäuser U, et al. Explanted cryopreserved allografts: a morphological and immunohistochemical comparison between arterial allografts and allograft heart valves from infants and adults. Eur J Cardiothorac Surg 1999;15:639-645.

8. Koolbergen D, Hazekamp MG, de Heer E, et al. The pathology of fresh and cryopreserved homograft heart valves: an analysis of forty explanted homograft valves. J Thorac Cardiovasc Surg 2002;124:689-697.

9. Cebotari S, Lichtenberg A, Tudorache I, et al. Clinical Application of Tissue Engineered Human Heart Valves
Using Autologous Progenitor Cells. Circulation 2006;114(1 Suppl):I132-I137.

10. Mitchell RN, Jonas RA, Schoen FJ. Pathology of explanted cryopreserved allograft heart valves: comparison with aortic valves from orthotopic heart transplants. J Thorac Cardiovasc Surg 1998;115:118-127.

11. Gellis L, Baird CW, Emani S, et al. Morphologic and histologic findings in bioprosthetic valves explanted from the mitral position in children younger than 5 years of age. J Thorac Cardiovasc Surg 2018;155:746-752.

12. Neves J, Monteiro C, Santos R, et al. Histologic and genetic assessment of explanted allograft valves. Ann Thorac Surg 1995;60(2 Suppl):S141-S145.

13. Krs O, Slizova D, Burkert J, et al. Impact of Processing on Surface Structure of Human Cardiac Valve Allografts. Acta Medica (Hradec Kralove) 2004;47:97-99.

14. Burkert J, Krs O, Vojacek J, et al. Cryopreserved Semilunar Heart Valve Allografts: Leaflet Surface Damage in Scanning Electron Microscopy. Zentralbl Chir 2008;133:367-373.

15. Goffin YA, de Gouveia RH, Szombathelyi T, et al. Morphologic Study of Homograft Valves before and after Cryopreservation and after Short-Term Implantation in Patients. Cardiovasc Pathol 1997;6:35-42.

16. Lupinetti FM, Christy JP, King DM, et al. Immunogenicity, Antigenicity, and Endothelial Viability of Aortic Valves Preserved at $4^{\circ} \mathrm{C}$ in a Nutrient Medium. J Cardiol Surg 1991;6:454-461.

17. O'Brien MF, Stafford EG, Gardner MAH, et al. A comparison of aortic valve replacement with viable cryopreserved and fresh allograft valves, with a note on chromosomal studies. J Thorac Cardiovasc Surg 1987;94:812-823.

18. Lisy M, Kalender G, Schenke-Layland K et al. Allograft Heart Valves: Current Aspects and Future Applications. Biopreserv Biobank 2017;15:148-157. 